\title{
Giant cutaneous horn
}

\section{Mrinal Gupta}

\author{
Consultant Dermatologist, Treatwell Skin Centre, Jammu, India
}

Corresponding author: Dr. Mrinal Gupta, E-mail: drmrinalgupta@yahoo.com

Sir,

A 72-year old female presented to us with a 10-year history of a gradually progressive growth over the forehead. Initially the patient had noticed a reddish discoloration over the site which was followed by the development of a skin colored plaque which had gradually progressed to its present size and had remained asymptomatic throughout. There was no history of trauma at the site or any history of similar lesions in the past. She had no systemic complaints. On examination, a single nontender pedunculated blackish cylindrical horny growth, hard in consistency of about $3 \mathrm{~cm}$ in length and $2 \mathrm{~cm}$ at base was present over left side of forehead (Fig. 1). Other cutaneous features of dermatoheliosis like seborrheic kerartoses and wrinkling were also present. There was no regional lymphadenopathy. Routine blood investigations, urine examination, electrocardiogram, and chest radiography were normal. On the basis of history and clinical examination, a diagnosis of cutaneous horn was made and the patient was advised surgical excision of the lesion for histopathological examination which was refused by the patient.

A cutaneous horn (cornu cutaneum) is a conical protrusion from the skin surface consisting of cornified material organized in the shape of an animal horn, usually affecting the head and neck region. Pathogenesis of horn formation in humans has not been fully elucidated, but it has been suggested to be due to abnormal accumulation, excessive adhesiveness, and compaction of keratin. It can arise from a variety of benign lesions (DLE, epidermal nevus, sebaceous adenoma, seborrheic keratosis, trichilemmoma, verruca vulgaris), premalignant lesions (actinic keratosis, arsenical keratosis, pagets disease, solar keratosis),

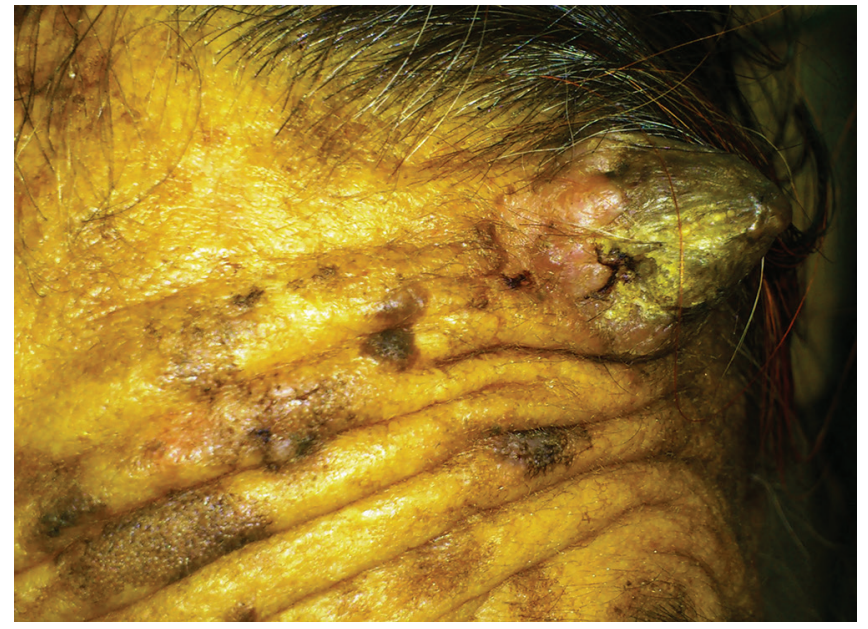

Figure 1: Cutaneous horn arising over the forehead.

and malignant lesions (squamous cell carcinoma, basal cell carcinoma, Bowen's disease, Kaposi sarcoma, keratoacanthoma). Histologically, there is a greatly thickened stratum corneum with scattered areas of parakeratosis. The horn at the base will display features characteristic of the pathologic process responsible for the development of the horn. Treatment is wide surgical excision with careful histological examination to exclude a focus of malignancy $[1,2]$.

\section{REFERENCES}

1. Akram H, Jing SS, Murahari S, David K. Cutaneous horn: Case report. Br J Oral Maxillofac Surg. 2011;49:73-5.

2. Mencía-Gutiérrez E, Gutiérrez-Díaz E, Redondo-Marcos I, RicoyJR, García-Torre JP. Cutaneous horns of the eyelid: A clinicopathological study of 48 cases. J Cutan Pathol. 2004;31:539-43.

Copyright by Mrinal Gupta. This is an open access article distributed under the terms of the Creative Commons Attribution License, which permits unrestricted use, distribution, and reproduction in any medium, provided the original author and source are credited.

Source of Support: Nil, Conflict of Interest: None declared. 